\title{
DIGITAL STYLE LEADERSHIP VIDEO BLOG (VLOG) PRESIDENT JOKO WIDODO: IN THE PUBLIC DIGITAL SPACE PREPARATION JURGEN HABERMAS
}

\author{
Sughron Jazila ${ }^{a}$ \& Agus Sugiharto ${ }^{b}$ \\ ${ }^{a}$ Master Student of Public Policy and Administration, Universitas Indonesia, Indonesia \\ ${ }^{b}$ Master Student of chool of Strategic and Global Studies, Universitas Indonesia, Indonesia \\ Corresponding Email: aazil.sughronjazila@ gmail.com \\ bSugihartoagus8@gmail.com
}

\begin{abstract}
The era of information society with the support of advanced technology development and rapid development. This has made a rapid change of community behavior. It is also responded quickly by President Joko Widodo in innovation in accordance with the times, so that the younger generation can capture and receive the technological era of technology. Combine his leadership style through "blusukan" by documenting it in the form of a video blog (Vlog) and uploaded on Youtube. This is made a digital public space for the people of Indonesia, in order to know the activities of the President. The author through the scope approach initiated by Jurgen Habermas tries to mean the analysis of secondary data sources such as books, literacy, journals, and online media to be used as references in the study of this paper. The results of the research idea of innovation that can be developed by further researchers.
\end{abstract}

Keyword : Style Leadership, President Joko Widodo, Vlog, Digital Public Space, Jurgen Habermas.

\section{INTRODUCTION}

The practice of democracy in modern society today has undergone considerable evolution. In a liberative way, democracy basically relies on the function of democratic institutions. Democracy, for example, presupposes a political party, a system of periodic elections for political leaders, a clear division of power between the legislature, the executive and the judiciary. Such a practice of democracy is of course insufficient, therefore such practice can't be the object of a democracy. Such institutional practice can only be placed in the context of a prerequisite for a democracy, as a prerequisite of such institutional practice can't be used as an indicator to audit democracy. today's democratic ritual has undergone a shift from its liberative, institutional character to a delibarative that guarantees the right of every citizen to participate in any political decision. For this development, no less examples. Various media both electronic and print media provide space for public debate on any government policy. The question is about democracy only to the practice deliberative as what is common in every society and democracy. the phenomenon of leadership Joko Widodo wants to show that democracy is not just up to liberative and deliberative practices. Using democratic theory from Giddens (2009) ${ }^{1}$, the article aims to explain that substantive democracy must also contain dialogical practice.

President Jokowi diligently makes video blog (vlog). The digital age is an incredibly busy online activity. Internet, smart phones, and social media networks are often considered an addictive blend in the digital age. Though the digital era is not solely about the problem that smells online and technology affairs. Virginia Heffernan, therefore, in his book Magic and Loss: The

\footnotetext{
${ }^{1}$ Giddens, A. (2009). Melampaui Ekstrim Kiri dan Kanan, Masa Depan Politik Radikal. Yogyakarta: Pustaka Pelajar.
} 
Internet as Art, not only sees the Internet as a technological artefact that facilitates daily work. The Internet has brought us to the era of revolution spread in the history of postagriculture human civilization and industrial revolution. The Internet with all its power compresses space and time and creates new space, collective space. This is what makes the Internet different from its predecessor technology. The digital era is also called VUCA which stands for volatility, uncertainly, complexity, and ambiguity, VUCA is a picture of the situation in the business world in the digital era.

The community first reached the consensus stage. Meanwhile, to reach the consensus stage, the community must make a satisfactory communication process. In the process of communication done, the participants make the other person understand the meaning by trying to reach the valid claims that are considered rational and will be accepted without any coercion as a result of consensus of the communication process. The claim of validity referred to by Habermas is; first, truth claims; second, claims of validity; the three claims of honesty; fourth, claims of comprehensibility.

In the context of Indonesia, as we all know that the year 2014 is the political year, where the Indonesian people will choose a presidential candidate who will lead the State of Indonesia in the next five years. In this case, the author tries to relate the theory of communicative action Habermas. To reach the consensus stage or in this case a presidential and vice presidential candidate is ultimately elected, a presidential and vice presidential candidate must communicate what his vision and mission has been for five years as leader.

\section{THEORY REVIEW}

\subsection{Digital Public Space}

Public Space as a means of political communication to the political system in democratization. It means we are in the process and it will continue until the time that can not be determined. This essay refers to the political freedoms and political participation that all communities have felt. But there are also those assume that democracy in Indonesia is not necessarily consolidated. If not consolidated, democracy is like a coming guest who will certainly go back.

Public space in the era of globalization is the market and can be used as a medium of communication, the existence of a forum or stage of political communication that is free from market or state influence. The analysis of Habermas, envisions today's complex society as three major components, namely the market economy (capitalism), bureaucracy ((state), and social solidarity (community), the locus of public political space lies in the component of social solidarity, at least in the era of globalization and democratization, has open public spaces that are freely accessible to the general public that is free to be accessed by the general public. Therefore, it should be open the public space, can be used as a means to communicate to discuss or resolve issues concerning the livelihood of many people.

\section{RESEARCH METHODS}

The research method used secondary data and literature review. Data taken from the national newspaper news relating to the object of discussion, the practice of democracy conducted by President Joko Widodo through online communication media is video blog (vlog).

\section{RESULTS AND DISCUSSION}

\subsection{Digital Public Space}

One of Jokowi's most popular activities is a program known as blusukan to slums that are generally located in periphery areas. One of the innovations and creativity of President Jokowi is to utilize social media when melalukan blusukan to the country that is using video blog (vlog) for media sharing to the people. So the public knows what the blusukan activity done by the President. Blog video is often 
used by millenial generation young people to do the arena of creativity and selfexistence. President Jokowi utilizes it as an effective digital public space for dialogue with the people. President Jokowi also often answers some questions and quizzes via video blog. In addition President Jokowi combines blusukan in a creative and innovative way through video blog. This blusukan program theoretically not only has a pragmatic and instrumental purpose, namely to know the problems experienced by the community, or simply socialize development plans and various other policies. This blusukan strategy contains a substantive purpose that relates to how the relationship between state and citizen, a relation that must be built on social beliefs that are not only communitarian but more importantly personal. With the strategy of the contradiction turned into a fun art performance. Various national media such as preaching how the demonstration of emotional mothers turned into jokes of laughter that entertain. This happens solely because morally the state (government) and the community share the moral belief that both parties will always do the best for the other.

In addition to blusukan, public hearing is one of the leadership strategies shown by Joko Widodo. Public hearings are conducted through open debate with various elements of society such as civil society coalitions and various other interest groups. In addition to open debate, public hearings are also conducted through online media networks. Every citizen, for example, can easily access various discussions, either by government agents internally, or between government and other interest groups. Through the same media people can participate in conveying their views, opinions or ideas, including in this case their anxieties and hopes.

The strong legitimacy of the public can only be done through public debate, ie every citizen can participate to convey their views. Public debate in this regard is one of the important features of democracy. Democracy allows the people to choose and decide who they want on terms of conditions, can come to produce good political leaders. Democracy provides a certain number of choices, which can not definitively be granted by a single party system (Giddens, 2009). Democracy is the right of all citizens who choose and form political organizations. This right can be seen as one among many other liberal rights. A so-called democratic country if it grants citizens the right to vote for selfgovernment through fair, secret, and fair elections and multiparty elections based on universal and fair voting rights for adults (Giddens, 2009). But enough election conditions for a democracy, Giddens distinguishes liberal, deliberative democracy from a dialogue of democracy.

Liberal democracy in principle only ensures procedurally how national and local leadership are selected. However, the system does not guarantee that the elected agents or actors exercise power democratically, in particular ensuring the right of citizens to actively participate in development. It is not surprising that liberal democracy tends to be elitist (Sujatmiko, 2002). In this elitist democracy only a few people or groups play a role. This situation is accompanied by weak accountability in the executive, legislative, and judicial sectors. Liberal democracy tends to reduce democracy at the time of the elections, when the people make their political choices. Theoretically this view is found in Huntington's explanation. According to Huntington (1991), procedural democracy or power competition through elections is the essence of democracy (in Sujadmiko, 2002). In principle procedural democracy is not the goal of a democracy. Procedural or electoral democracy is only a prerequisite for a democracy. This means merging democracy only in the selection process is a view that tends to be reductive. Democracy is reduced to samata. Democracy like this ignores it is run by government agents elected by the people. To ensure the government agency chosen by the people exercises its power, the following two democratic mechanisms and patterns can be considered as indicators for measuring democracy. These two mechanisms and patterns are deliberative and dialogical democracies. According to Giddens (2009), 
deliberative democracy goes against the liberal democracy. Liberal democracy consists of a series of representative institutions, guided by a certain value. Liberative democracy is a way to gain or realize, gain, agreement on various policies in the political sphere. In representative mechanisms for example, the legislative decision is recognized as a representation of the will of the people. Instead the deliberative ideals, quoting David Miller, rests on the assumption that political preference or priority will be in conflict and that the goal of democratic institutions must be to resolve the conflict. In order for the resolution of the conflict to contain a democratic dimension, problem solving must take place through open and free debate on the question concerned with the objective of reaching a mutual agreement or decision.

According to Cunningham (2002), the core theory of deliberative democracy relates to legitimacy, a definite preference, and the aggregation of interests in a political policy. The legitimacy of the democratic process occurs when the citizens have a deliberative opportunity to participate in policy issues and how they should be implemented. In this context citizens are involved in a plausible debate over the policy. Through this sensible debate citizens are actively involved in negotiations to fight for their interests. In the process of negotiating preferences and the value of the debate may change. Of course, the main problem in deliberative democracy is not the result of debate but the debate itself is the process by which public policy gets legitimacy.Based on that explanation, Cunningham (2002) asserted that deliberative democracy surpassed the majority vote. In this case deliberative democracy is a process that has educative power, can generate power on community level, promoting fair, rational, and equitable democratic results between citizens' interests and state policy (Cooke, 2002).

Mill and Arendt as cited by Cunningham (2002) argue that citizen participation in public affairs is good in itself, not merely because participation is instrumental, but because with the widespread participation of citizens a political decision will be better qualitatively. Participation will improve the moral, practical or intellectual quality of all participating citizens. Thus, citizens will become better not only in their context as citizens but also as individuals. In addition, deliberative democracy will also enhance the common good of a community. Deliberative democracy will enable individuals to become conscious and consolidate their membership collectively. When a person is not involved in a policy, at the same time that person will feel excluded from a community. But when someone is involved, the person will feel as part of a community. Of course this will increase individual responsibility for the common good in the community. Another benefit of a deliberative democracy is that deliberative democracy guarantees a more just and fair decision. Finally, through public debate in a deliberative democracy a policy is guaranteed to be more rational.

\subsection{Deliberative Democracy}

Deliberative democracy can only be implemented if there is a public space. In the public sphere everyone can be present to discuss and discuss issues of concern to both individuals and community groups. In the context of Habermas Lubenow (2012), public space is an intermediary space mediating the state, political system, and private sector that serves as lifeworld. In a public sphere a discursive formation of political opinion and will can arise. Public spheres are not an institution or organization, but a space that can happen anywhere. Such public spaces can occur in a coffee shop where everyone can come and talk about public issues. This public space can occur if there is a guarantee from the state not to supervise a totalitarian citizen.

Dialogic democracy differs from all other patterns of democracy. Dialogic democracy does not imply that all denunciations or conflicts can be overcome through dialogue. Dialogic democracy also does not imply that in any system or relationship, the dialect must be continuous. Giddens' firm dialogue should be 
understood as the ability to foster active trust through appreciation of the integrity of others. Trust in this case is a means to organize social relationships over time and place. Trust perpetuates the 'necessary silence' that allows individuals or groups to live their lives in harmony while remaining present in each other's social relationships.

According to Giddens, individuals who have a good understanding of their own emotional state, and who are able to communicate them effectively to others personally, are potentially more prepared to develop broader citizenship duties. Social communication is done by the public, that's why in its development the word deliberation is also associated with the word public. Cook, Carpini, and Jacobs (2007: 28) lists the three principles of public deliberation outlined in the following paragraphs:

First, public deliberation is a tool for educating and training citizens. The function of education in this case is by building citizens who have information well, enlightened, and have attitude that is not easily manipulated. In addition the deliberation system trains residents to generate trust in political institutions and fellow citizens themselves. Second, participation in public deliberation is seen as a tool for building citizen morale. These citizen morals are built and tested primarily as they are discussing a common issue. In the discussion there will be a battle of interests and values that they must decide together. In this way citizens are trained to accept that there should be decisions that are not only good for a few people, but for the common good.

Third, public deliberation is seen as a unique mechanism for generating a common decision. Public deliberations are used as a method to discuss and negotiate on issues to produce decisions. This method is considered to be able to break the previous tradition, so it is considered different.

To achieve an ideal deliberation process, Habermas (1996) as quoted in Coleman \& Blumler (2009: 18) delivered four suitable conditions. According to him these four conditions are so essential to a deliberation process, as well as the results of the deliberation itself. The four conditions are:

i. Everyone should be able to convey their own ideas openly and at the same time be able to give criticism of other ideas.

ii. The concept of power, associated with social status, should be removed.

iii. Arguments based on a tradition or dogma must be raised.

iv. A truth must be raised from consensus.

\subsection{Political Communication: Society, Media, and Government}

Research conducted is closely related to the theme of political communication. The connection is evident from the argument that a comment analyzed is a communication message given by the community to the government through online media. Cangara (2011: 30) formulating political communication as a process of passing symbols or symbols of communication containing political messages from a person or group to others in order to open insights or ways of thinking, and influence the attitudes and behavior of the targeted political audiences. Meanwhile, according to Soesanto (1986) as quoted in Ardial (2010: 28) interpret political communication as a communication directed at achievement of influence in such a way that the problem discussed by this type of communication activities, can bind all its citizens through sanctions determined jointly by institutions political. Political communication activities are seen as the connecting road between the social community and the state. 


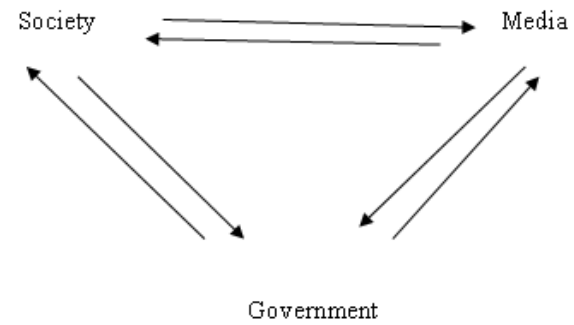

Figure 1. Pattern of Cooperation

Relationship between

Society, Media and Government (Source: Cangara, 2011: 109)

\subsection{Millennial Generation Leadership}

If analyzed in a deliberative context, Jokowi always involves public debate for each of their policies. President Jokowi uploaded the process and the results of working meetings through social media sharing. With this method every policy they produce can be criticized and responded to by the community. In addition, they also conduct public debates through public hearings. Through public debate they submit work plans and government policies on the one hand; and on the other side they getcommunity response. In public debates both state (government) and society can express their opinions on rational grounds. Of course, through public debate is expected to achieve synergy between the interests of the state on the one hand and the interests of society on the other.

Through the blusukan strategy, Joko Widodo strives to continue dialogue (dialogist democracy) with citizens. Of course blusukan strategy does not merely have an instrumental purpose that is to know the problems that occur in the community. Moreover, the blending strategy substantively has a moral purpose. Through blusukan strategy and through digital leadership style that is video blog, Joko Widodo guarantee trust between citizen with government, that government will always be on the side of society. Trust will strengthen and improve public morale.

Strong public morals will minimize conflicts between state and government with citizens or communities as is the case in other parts of Indonesia or with the previous government. The conflict between street vendors and Satpol PP is an example of a deficit of dialogical democracy. This means that dialogue democracy Joko Widodo convinces the public that any government and state policy will bring the greatest benefit to the people.

Video Log is a creative content created by someone to share their life diary in a form of video that deliberately aired to many people for free. Generally Vlogs are created to present interesting, funny, silly, unique, educational, and other information, as well as Vlog creators called vloggers. Especially for Vloggers who use Youtube for Vlogging or sharing vlogs called Youtuber.

In order for Indonesians, including their young generation, to know and take part in all government policies, President Joko Widodo (Jokowi) chose to use social media in communicating with them. The President includes actively using various social media, from facebook, twitter, to youtube.

"More effectively we use social media. Therefore, now in delivering government programs I also use video blog (vlog) in communicating with young children. I also did a question and answer to ask the problems that exist in the field to our young generation to then I replied, "said President during a stop at a restaurant in Purwakarta, West Java.

President Jokowi is quite active to upload vlognya on his personal Facebook and YouTube account. In a number of his latest vlogs, President Jokowi deliberately involves the younger generation to be able to participate actively in development in their own way.

"I think this way of communicating is important so that we can convey what has been done by the government, what programs have been completed and are running," said the President.

Such ways, assessed by President Jokowi, will be able to explain the development of 
each program, so that communication with young people and the people are always connected. According to the President, the vlog he created often arises out of spontaneity with what he sees on the ground. He cited the process of making a vlog in Sei Gong Reservoir in Batam, Riau Islands, which he uploaded on March 31, 2017 and then .

"Spontaneous, sometimes we go to the field. For example, the time to reservoir Sei Gong kok many workers. I asked where they came from, some from Medan, Tanjung Pinang, Balikpapan, Makassar, NTT, all kinds of things, instantly spontaneous when I made the vlog, "said the President.

Of course the vlog he made with the workers in Sei Gong Reservoir was not just a mere formality. There are goals to be achieved from these activities that may not have been realized by the community.

President Jokowi is well-known as a country leader who often uploads video blogs (vlogs) compared to other world leaders. The 7th President of Indonesia is diligently uploading his vlogs to YouTube and Facebook video sharing services. Vlog father of three children is told various activities as a leader of a country. Not infrequently, the former mayor of Surakarta is also uploading vlogs containing togetherness and familiarity with leaders from other countries.

The names of world leaders, such as Saudi Arabia's King Salman bin Abdulazis alSaud, Turkish President Recep Tayyip Erdogan, and Canadian Prime Minister Justin Trudeau have been included in the vlog of President Jokowi. Finally, his vlog with PM Trudeau was taken in between The G20 Summit in Hamburg, Germany, also stole the attention of Indonesian citizens

Based on one of the media sources online, Liputan6.com, on Monday $(10 / 6 / 2017)$, the YouTube channel of President Joko Widodo has been followed by 321 thousand subscribers with the number of video that he aired now as many as 260 videos, both berupavlog and other videos. With the number of videos are not small and get a lot of views, usually so income for people who call themselves vlogger. The question is how much is the income of President Jokowi's channel?

From the results of the source liputan6.com, video owners who video on YouTube managed to get 100 thousand views or more, usually get US $\$ 50$ - US $\$ 100$ or about Rp 600 thousand to $\mathrm{Rp} 1.3$ million. However later, it is known that the value of video revenue from YouTube vary from one to another. This is due to several factors. To estimate the amount of income received by President Jokowi's channel, we experimented with a YouTube revenue calculation site, Social Blade and Dbase.tube.

President of Indonesia, Joko Widodo, appealed for Vocational High School (SMK) to add new majors that hone skills in the technology and digital sector. Otherwise, local human resources will be left behind and unable to compete in the global sphere. One of the majors Jokowi recommended is the development of skills to make a video blog or often called a vlog. According to him, SMK should not only be fixated on the majors of machinery, buildings, electricity, and other majors that have existed since the first. This is an illustration that President Jokowi is one example of a leader who applies millenial generation leadership style.

\section{CONCLUSION}

The role of leaders in responding to the times. This is the response to technological developments. President Joko Widodo through the blusukan program and video blog that is often done through social media, especially on Youtube, is a typical leadership style innovation with millenial generation. Vlogs can be used as digital public space. The author attributes this to the concept of Jurgen Habermas's perspective with his public space. This is when dianalis, President Joko widodo in through communication with the people, utilizing technological sophistication. So 
that people can know the work and activities of President Joko Widodo.

\section{CONFLICT OF INTEREST}

This paper have no conflict of interest.

\section{REFERENCES}

Ali, Denny Januar. (2006). Manuver Elit, Konflik, dan Konservatisme Politik. LKIS. Yogyakarta.

Cunningham, F. (2002). Theories of Democracy, a Critical Introduction. Routledge. London and New York.

Giddens, A. (2009). Melampaui Ekstrim Kiri dan Kanan, Masa Depan Politik Radikal. Pustaka Pelajar. Yogyakarta.

Habermas, Jurgen. (1984). The Theory of Communicative Action (Translated by Thomas McCarthy). Volume 2 . Beacon Press. Boston.

Hardiman, F. Budi. (2010). Etika Politik Habermas. Salihara: Makalah Seri Kuliah Umum.

Hardiman, F. Budi. (2008). Teori Diskursus dan Demokrasi. Jurnal Diskursus Vol. 7, 1-25.

McCarthy, Thomas. (1979). Communication and The Evolution of Society. Heinemann. London.

Sujatmiko, IG. (2002). Demokrasi Pasca Pemilu. Masyarakat: Jurnal Sosiologi, Vol. 11. 